\title{
Kentiçi Otopark Analizi: Elazı̆ İli Örneği
}

\author{
Ahmet ATALAY ${ }^{*}$, Yunus İÇEN ${ }^{2}$ \\ ${ }^{1}$ İnşaat Mühendisliği, Mühendislik Fakültesi, Atatürk Üniversitesi, Erzurum, Türkiye \\ 2 İnşaat Mühendisliği, Mühendislik Fakültesi, Atatürk Üniversitesi, Erzurum, Türkiye \\ ${ }^{* 1}$ ahatalay@ atauni.edu.tr, ${ }^{2}$ yunusicen@gmail.com
}

Öz: Gün geçtikçe artan nüfus, sosyo ekonomik gelişmişlik beraberinde otomobil sahipliğini artırmaktadır. Gelişmekte olan kentler artan otomobil sahipliği ile beraber trafik tıkanıklığı, gürültü, hava kirliliği, zaman kaybı ve otopark sorunları gibi kent içi ulaşım sorunları ile karşı karşıyadır. Bu çalışmanın amacı ülkemizin gelişmekte olan kentlerinden Elâzı̆̆ ili kentiçi ulaşım sorunlarından otopark sorunu ele alınmıştır.

Çalışma kapsamında Elâzı ̆ ili için otopark ihtiyacı bugün ve gelecek 20 yıl için hesaplanmıştır. Elâzığ kent merkezinde hizmet veren yol dışı otoparklar standart ve yönetmeliklere göre uygunlukları incelenmiştir. Çalışma da ayrıca Gazi, Hürriyet ve Vali Fahri Bey Caddelerinde yol kenarı park etütleri yapılmıştır. Park etütleri belirtilen caddelerde eş zamanlı olarak iki haftalık zaman diliminde yapılmıştır.

$\mathrm{Bu}$ çalışma sonucunda Elazı̆̆’’n mevcut otopark ihtiyacının yapılan hesaplarla yetersiz olduğu tespit edilmiştir. Doğu Katlı otopark1, Hükümet konağı otoparklarının standart ve yönetmeliklere göre uygun olarak planlandığı belirlenmiştir. Etüdü yapılan diğer otoparklarda ise tasarım hataları gözlenmiştir. Yol kenarı park etütlerine göre Gazi Caddesi üzerinde araçların 30 derece ile park etmesi halinde caddenin park kapasitesinin \%22, 45 derece ile park etmesi halinde \%64 oranında artacağı belirlenmiştir.

Anahtar kelimeler: Otopark Analizi, Yol kenarı Park, Yol dışı Park, Otopark Şekilleri, Kentiçi Otopark Sorunu.

\section{Urban Parking Analysis, A Case Study: Elazığ Province}

Abstract: The population, which is increasing day by day, increases automobile ownership along with socio-economic development. Developing cities are faced with urban transportation problems such as traffic congestion, noise, air pollution, waste of time and parking problems with increasing car ownership. The aim of this study is to address the problem of parking in the city of Elazig, one of the developing cities of Turkey.

Within the scope of the study, the need for parking for Elâzı̆̆ province is calculated for the present and next 20 years. The compliance of the off-road parking lots in Elazig city center according to the standards and regulations were examined. In addition, roadside parking surveys were conducted in Gazi, Hürriyet and Governor Fahri Bey Streets. Parking surveys were carried out simultaneously in the specified streets for two weeks.

As a result of this study, it was found that the existing parking need of Elâzı̆̆ was insufficient with the calculations made. It has been determined that the parking lots of the East Storey and the Government mansion car parks are planned in accordance with the standards and regulations. Design errors were observed in the other car parks under investigation. According to the roadside studies, if the vehicles are parked at 30 degrees on Gazi Street, the parking capacity of the street will increase by $22 \%$ and $64 \%$ if it is parked at 45 degrees.

Key words: Parking Analysis, On-Road Parking, Off-Road Parking, Parking Lot Types, Urban Parking Problem.

\section{Giriş}

Son yıllarda şehirlerimizde köylerden kente göç ile beraber nüfus hızla artmaktadır. Bu göç hareketi genellikle ekonomik kalkınma ve çocukların eğitimi düşünülerek bireyler tarafından yapılmaktadır. Şehirlerde artan nüfus ile beraber bu çoğalma kentlerde ekonomik, sosyal ve çevresel kalkınmaları da hızlandırmaktadır. Dünya kamuoyunda bu durum "sürdürülebilir kalkınma" olarak tanımlanmış ve bunun sürekliliğinin sağlanmasına yönelik ciddi çalışmalar yapılmıştır. Sürdürülebilir kalkınmaya etki eden en önemli faktörlerden birisi "ulaşım" dır. Çünkü ulaşımın ekonomik, sosyal ve çevresel faktörlere etkisi oldukça fazladır [1-3].

Günümüzde ekonomik gelişme ile birlikte, taşıt sahipliğinin hızla artması sonucu birçok kentimizde park yeri sorunu yaşanmaktadır. Mevcut alt yapının yetersizliği de bu sorunu içinden çıkılmaz bir hale getirmektedir. Park sorununun çözülmesi için gerekli etütlerin yapılarak yerel yönetimlerce bir park politikasının belirlenmesi

\footnotetext{
* Sorumlu yazar: ahatalay@ atauni.edu.tr. Yazarların ORCID Numarası: ${ }^{1} 0000-0002-8476-8900,{ }^{2}$ 0000-0002-0083-0739
} 
zorunludur. Bunun yanında eğitim ve denetimin de bu politikanın içinde yer alması gereklidir [4]. Sürücülerin mevcut trafik akışına ek olarak park yeri aramaları için yaptıkları yer değiştirmeler ilave trafik yükü oluşturmaktadır. Zaman kaybı, yakıt tüketimi, sinir stres sürücü davranışı olumsuz etkiler. Bu sebeple otopark sorunları incelenirken trafik akışı da incelenmelidir [5].

Otopark sorunları hakkında literatürde yapılmış olan çalışmaları üç grupta toplanabilir. Birinci grup çalışmalar otopark ihtiyacı ve kapasite analizi yapılan çalışmalardır. Yol kenarı ve yol dışı park etütleri yapılarak çözüm önerileri belirlenmesi [4-9], kentler için otopark planlamasında etkili faktörlerin belirlenmesi, kentler için otopark planlamasının önemi [10-12], kentlerde trafik yoğunluğu, arz talep ve otopark yer seçimi ilişkisinin incelenmesi [13-15], çalışmalardır. Ayrıca otopark yönetimi [16-18], otopark tasarım ve projelendirilesi [19-21], hastane otoparklarının tasarlanması [22], üniversite kampüs otoparkları için etütler [23, 24], yol kenarı park yapma alışkanlıklarının incelenmesi [25], açık ve kapalı otoparkların özelliklerinin incelenmesi [26] çalışmalarıdır.

İkinci grup çalıșmalar akıllı otopark planlama ve işletme çalışmalarıdır. Klasik ve otomatik otoparkların karşılaştırılması[27], akıllı otopark sisteminin simülasyonu [28], otopark sorununa RFID (Radio Frequency Identification-Radyo frekanslı tanıma) teknolojisini uygulama [29], teknolojik, çevreci, daha az yer kaplamasına rağmen daha çok araç park kapasitesine sahip, sürücülere kolaylık ve güvenlik sağlayan tamamen otomatik bir otopark prototipi[30], otomatik otopark sistemlerinin avantajlar1 [31], ak1llı otoparklarda ödeme sisteminin NFC ( Yakın Alan İletişimi) kartlarla yapılması[32], özellikle internet olmayan yerlerde IPS (Indoor Positionin Systemİç mekân Konumlandırma Sistemi) teknolojisinin kullanılması [33], otopark sorunun çözümünde otopark kılavuz bilgi sistemlerinin (OKBS) uygulamaları [34] çalışmalarıdır.

Üçüncü grup çalışmalar mevcut otoparkların işletme ve yönetimi bakımından memnuniyet tespiti için yapılan çalışmalardır. Kentlerde park-et devam-et sistemlerinin uygulamaları için kullanıcılara anket uygulaması [35], kent merkezinde otopark yönetim politikalarını belirlemek amacı ile hane halkı anketi uygulaması çalışmaları yapılmıştır [36-37]. Üniversite kampüslerinde otopark sorununa etki eden faktörleri belirlemek amacı ile anket uygulaması [38-40], otopark ve yeşil alan sorunlarını tespit etmek amacıyla anket uygulaması [41] çalışmalarıdır. Ayrıca kentiçi alternatif otopark hizmetlerinin sunumu, Sürücülerin park etme tercih ve tutumları belirlemek amacı ile anket uygulama çalışmaları $[42,43]$ yapılmıştır.

$\mathrm{Bu}$ çalışmanın amacı kentlerde otopark ihtiyacının belirlenmesi ve gelişmekte olan kentlerde karşılaşılan otopark sorunlarını tespit etmek ve öneriler sunmaktır. Bu çalışmada nüfus ve araç sayısı dikkate alınarak Elâzı̆̆ ili için otopark ihtiyacı belirlenmesi yapılacaktır. Bu çalışmanın önceki çalışmalardan farkı, iki haftalık zaman dilimlerinde trafiğin zirve saatlerinde yol kenarı ve yol dışı park etütleri eş zamanlı olarak yapılmış çalışmanın verileri elde edilmiştir. Elde edilen veriler kullanılarak yapılan analizler sonucu yol kenarı ve yol dışı parkların doluluk oranları tespit edilmiştir.

\section{Materyal ve Metot}

Bu çalışmada otopark ihtiyacı belirlenmesi için materyal olarak Elâzı ̆̆ ili kent merkezindeki nüfus ve araç sayıları kullanılmıştır. Bu veriler Türkiye İstatistik Kurumu (TUİK) den elde edilen veriler kullanılmıştır (Tablo $1)$.

Tablo 1. Elâzı ̆g ili nüfus ve araç bilgileri [44]

\begin{tabular}{|c|c|c|c|c|c|c|c|c|c|}
\hline Yll & $\begin{array}{l}\text { Elazığ } \\
\text { Nüfusu }\end{array}$ & $\begin{array}{l}\text { Erkek } \\
\text { Nüfusu }\end{array}$ & $\begin{array}{l}\text { Kadın } \\
\text { Nüfusu }\end{array}$ & $\begin{array}{l}\text { Nüfus } \\
\text { Yoğunluğu }\end{array}$ & $\begin{array}{l}\text { Nüfus } \\
\text { Artış } \\
\text { miktarı } \\
(\%)\end{array}$ & $\begin{array}{c}\text { Otomobil } \\
\text { Sayısı }\end{array}$ & $\begin{array}{c}\text { Otomobil } \\
\text { Artış } \\
\text { miktarı } \\
(\%)\end{array}$ & $\begin{array}{c}\text { Kamyonet } \\
\text { Sayısı }\end{array}$ & $\begin{array}{c}\text { Kamyonet } \\
\text { Artış } \\
\text { miktarı } \\
(\%)\end{array}$ \\
\hline 2009 & 550.667 & 273.212 & 277.455 & $59 / \mathrm{km}^{2}$ & 1,16 & 36.216 & 7,56 & 11.690 & 12,42 \\
\hline 2010 & 552.646 & 272.500 & 280.146 & $59 / \mathrm{km}^{2}$ & 0,36 & 39.367 & 8,00 & 13.485 & 13,31 \\
\hline 2011 & 558.556 & 277.151 & 281.405 & $60 / \mathrm{km}^{2}$ & 1,07 & 43.283 & 9,05 & 15.219 & 11,39 \\
\hline 2012 & 562.703 & 279.599 & 283.104 & $60 / \mathrm{km}^{2}$ & 0,74 & 46.786 & 7,49 & 16.903 & 9,96 \\
\hline 2013 & 568.239 & 282.049 & 286.190 & $61 / \mathrm{km}^{2}$ & 0,98 & 50.590 & 7,52 & 18.154 & 6,89 \\
\hline 2014 & 568.753 & 281.583 & 287.170 & $61 / \mathrm{km}^{2}$ & 0,09 & 54.277 & 6,79 & 19.300 & 5,94 \\
\hline 2015 & 574.304 & 285.511 & 288.793 & $62 / \mathrm{km}^{2}$ & 0,98 & 58.494 & 7,21 & 20.711 & 6,81 \\
\hline 2016 & 578.789 & 287.991 & 290.798 & $62 / \mathrm{km}^{2}$ & 0,78 & 62.731 & 6,75 & 22.121 & 6,30 \\
\hline 2017 & 583.671 & 290.692 & 292.979 & $63 / \mathrm{km}^{2}$ & 0,84 & 67.192 & 6,64 & 23.550 & 6,06 \\
\hline 2018 & 595.638 & 296.641 & 298.897 & $64 / \mathrm{km}^{2}$ & 2,05 & 70.389 & 4,54 & 24.737 & 4,79 \\
\hline
\end{tabular}

Bu çalışmada otopark etütleri materyal olarak Elâzı ̆ ili kent merkezindeki otoparklardan elde edilen veriler kullanılmıştır. Çalışmanın veri tabanı 01.04.2019-14.04.2019 zaman diliminde sabah, öğle, akşam saatlerinde 
Elâzı̆̆ kent merkezinde yol kenarı ve yol dışı park gözlemleri sonucu elde edilmiştir. Gözlemler sabah, öğle ve akşam saatleri 09.00-11.00, 13.00-15.00, 17.00-19.00 saatleri arasında 30 dakikalık aralıklarla yapılmıştır.

\subsection{Otopark ihtiyacının belirlenmesi}

$\mathrm{Bu}$ çalışma kapsamında literatürde yapılan araştırmalar sonucunda ABD ve Almanya'da otopark hesaplamalarında kullanılan kabuller dışında özellikle ülkemize benzer ülkeler için yapılan kabullere rastlanılmadığı için var olan kabuller kullanılmıştır. ABD ve Almanya'da otopark hesaplamalarında kullanılan kabuller şu şekildedir [45].

I. ABD'de büyük şehirlerde pik saatlerde şehirdeki tüm araçların \%12'sinin merkez bölgede park edeceği, küçük şehirlerde ise \%18' inin merkezde park edeceği göz önüne alınır.

II. Almanya' da ki gözlemlere göre

a) Kentteki her 5-8 araca karş1 kent merkezinde 1 adet otopark yeri düşünülür.

b) Kent içi otopark ihtiyacı (P) için formül:

$$
P=\frac{E}{k * D}
$$

\section{P: Otopark ihtiyac1}

E: Kentin toplam nüfusu.

D: Araç başına düşen nüfus.

k: Yöresel katsayı ( 3-5 )

c) Şehir merkezinde her gün giren araçların \%7-9'u için 1 otopark yeri hesaplanır.

Bu çalışmada otopark ihtiyacı araç sayısına göre ve nüfusa göre olmak üzere iki farklı şekilde belirlenmiştir. a. Araç sayısına göre: ABD ve Almanya'da otopark hesaplamalarında kullanılan kabullere göre büyük şehirlerde \%12 ve küçük şehirlerde \%18 belirtilmiştir. Elâzı ğ ili için şehir merkezinde park edecek araçların oranı kabul oranlarına göre \%15 olarak kabul edilmiştir. Şehir merkezindeki araç sayısının şehirdeki otomobil ve kamyonet araç sayılarının toplamının \%15'i dikkate alınarak otopark ihtiyacı belirlenmiştir.

b. Nüfusa göre: Yukarıda açıklanan (1)'nolu eşitlik kullanılarak otopark ihtiyacı belirlenmiştir. Yöresel katsayı Elâzı̆̆ ili için 5 olarak kabul yapılmıştır.

\subsection{Park etütleri}

Park etütlerinin gayesi ne kadar süre ile park edildiği, işyeri sahiplerinin ve vatandaşların ne kadar yararlandığı, daha fazla kapasite ile nasıl hizmet verilebileceği gibi verileri elde etmek için yapılır. Genelde merkezi caddelerde, iş merkezlerinin yoğun olduğu yerlerde yapılır. Otopark etütleri yol dışı park etüdü ve yol kenarı park etüdü olacak şekilde ikiye ayrılır [5].

Kanun ve yönetmeliklerle ebatları, alanları, kullanım çeşidi ve fiyatı belirlenen özel otoparklara araçların park etmesine yol dışı park olarak adlandırılır. Bu parklar; açık otopark, kapalı otopark, katlı otopark, zemin altında veya üstünde olacak şekilde yapılabilirler.

Araçlarını otoparka bırakanlar bir miktar yol yürümek zorunda olduklarından yol dışı otoparkların yerlerinin belirlenmesinde dikkatli davranılması gerekmektedir. Yürüme mesafesinin maksimum 300 m olması idealdir [4]. Yol kenarı veya kaldırım kenarı da denilen yol kenarı park, araçların caddelerde kaldırım kenarlarına park etmesi olayıdır. Yol kenarı parklarının amacı mevcut trafik akışını sağlamakla beraber bireylerin banka, iş merkezleri, alışveriş gibi nedenlerle kısa süreli olarak araçlarını park etmelerine olanak sağlamaktır. Mümkün olabildiğince cadde kenarı parklanmaları bu kısa süreli müşterilerin kullanması gerekmektedir.

\subsection{Yol dışı park etütleri}

Yol dişı park etüdü için, 12 saatlik uzun veya sabah 09:00-11:00 ve öğlen 14:00-16:00 saatleri arasında kısa süreli etütler yapılması uygundur. Etüt için önce, bir harita üzerinde yol dışı park yerleri tespit edilir. Bunların kapasiteleri öğrenilir. Daha sonra belirlenen park yerleri dolaşılarak föyler doldurulur ve föylerdeki bilgilerle önceden belirlenen bilgiler karşılaştırılarak etüt tamamlanır.

Yol dışı park etüdü için kullanılacak sayım föyünde, park yeri, taşıt sayısı ve park süreleri yazılır. Yol kenarı park etüdünde olduğu gibi yol dışı park yerleri 15, 20, 30 dakikada bir dolaşılarak föy doldurulur. 
Sayım föyünde, ayrıca yol dışı park yerinin (m2) olarak alanı yazılarak, her park yerinin günün belirli zamanlarında \% kaç dolulukla çalıştığı, araç sayısı ile park kapasitesi karşılaştırılarak, park düzenlemesinin uygun olarak yapılıp yapılmadığı da araştırılabilir. Uygun bir şekilde düzenlenmiş bir yol dışı park yerinde, sirkülasyon yolları da dahil olmak üzere araç başına $30 \mathrm{~m} 2$ alan alınması yeterlidir. Yol dışı park etüdü sonucunda, her küçük bölge için park kapasitesi ve ihtiyacı grafiklerle belirtilir [4].

Bu çalışma kapsamında yol dışı parkların uygun olup olmadıkları TS 10551 'nolu standart ve 2018 yılında yayınlanan Otopark Yönetmeliğinde belirtilen esaslar dikkate alınarak belirlenmiştir [44,45]. Belirtilen standart ve yönetmeliğe göre yol dışı parkların ölçüleri aşağıda maddeler halinde belirtilmiştir.

1) Otopark giriş kapısı genişliği net 2,75 metreden az olamaz.

2) Otopark giriş kapısı yüksekliği net 2,00 metreden az olamaz.

3) Otopark iç yüksekliği kiriş altı dâhil olmak üzere hiçbir yerde net 2,10 metreden az olamaz.

4) Umumi otoparklarda rampa eğimi $\% 15$ 'ten fazla olamaz. Umumi otoparklar haricinde, otopark ihtiyacını bünyesinde karşılayan binalarda otopark rampası eğimi \%20'den fazla olamaz.

5) Otopark rampa genişliği 2,75 metreden az olamaz. Rampalar dönüş kısımlarında asgari 2,75 metre iç yarıçapında düzenlenir [45].

6) Rampa eğimi \%10, en çok \%12 olmalıdır.

7) Genişlik Düz Rampada 3,30 m, kurplu rampada iç iz 3,60 m, dış iz 3,10 m, spiral rampada iç kurp çap1 9,00 m, dış kurp çapı 16,50 m [46].

TS 1051 de rampa eğimi en çok \%12 olmalıdır belirtilmesine rağmen 2018 yılında yayımlanan Otopark Yönetmeliğinde rampa eğimi umumi otoparklarda en fazla \%15, umumi olmayan otoparklarda ise en fazla \%20 olması gerektiği belirtilmiștir [46,47]. Bu çalışmada kapsamında incelenen otoparklarda rampa eğimin en fazla \%15 olması standardına göre değerlendirilmiştir.

\subsection{Yol kenarı park etütleri}

Yol kenarı park etüdü de hafta içi yani iş günlerinde yapılır. Etüt yapılacak saatler 07:00-19:00 saatleridir. Eğer 12 saat etüt yapılamıyorsa 6 saat yapılabilir bu durumda etüt yapılacak saatler 09.00-11.00, 13.00-15.00 ile 17.00-19.00 arasında yapılır. Etüt yapacak personel 15 veya 30 dakika arayla park eden araçlar sayılır ve araçların plakaları önceden hazırlanan etüt föylerine kaydedilir. Böylece sayım işlemi belirlenen tarihler arasında yapılır. Etüt için önce park süreleri incelenir. Görevlinin etüt yapacağı bölgenin özelliğine göre kaç dakikada bir gözlem turu yapacağı belirtilir (15 dk. veya $30 \mathrm{dk}$. gibi). Ancak verilen bu süre içinde, etüt yapacağı bölge içi yolları dolaşabilmelidir. Görevli sokağın bir ucundan bir ucuna giderek yol kenarı parkındaki araçların plaka numaralarını yazar. Bu arada, büyük bir mağazanın etrafında yol kenarı parkının çalışanlar veya müşteriler tarafından ne miktarda kullanıldığını anlamak istenilebilir. Genellikle yol kenarı parkları çalışanlar kullanıyor ise çalışanlar için yol dışı park yeri gereksinimi bulunuyor demektir. Föylerde değişik turlara ait sütunlarda aynı plaka numarasının tekrarlanması ile aracın ne kadar süre ile park ettiği anlaşılır.

Etüde bu şekilde devam edilerek hazırlanan föylerdeki bilgiler bir toplama tablosunda özetlenir. Toplama tabloları etüdün amacına göre değişik şekillerde düzenlenebilir. Park süreleri olarak 15 dakikadan az veya 15-30 dakika gibi süreler alınabilir. Toplama tabloları bir sokak, küçük bir bölge veya bütün bir şehir için hazırlanabilir. Ayrıca grafik ve haritalarla da daha uygun bir şekilde sonuçlar verilebilir.

\subsection{Park düzenleme şekilleri}

Parkların düzenleme esasları Türk Standardı TS 10551'de hem yol dışı hem de yol kenarı parklar için belirtilmiştir.

\subsubsection{Yol dıșı Park Düzenleme Şekilleri}

Yol dışı parkları $30^{\circ}, 45^{0}$, 60 ve $90^{\circ}$ olarak düzenlenir her biri için ayrı manevra aralıkları Şekil 1'de gösterilmiştir. 


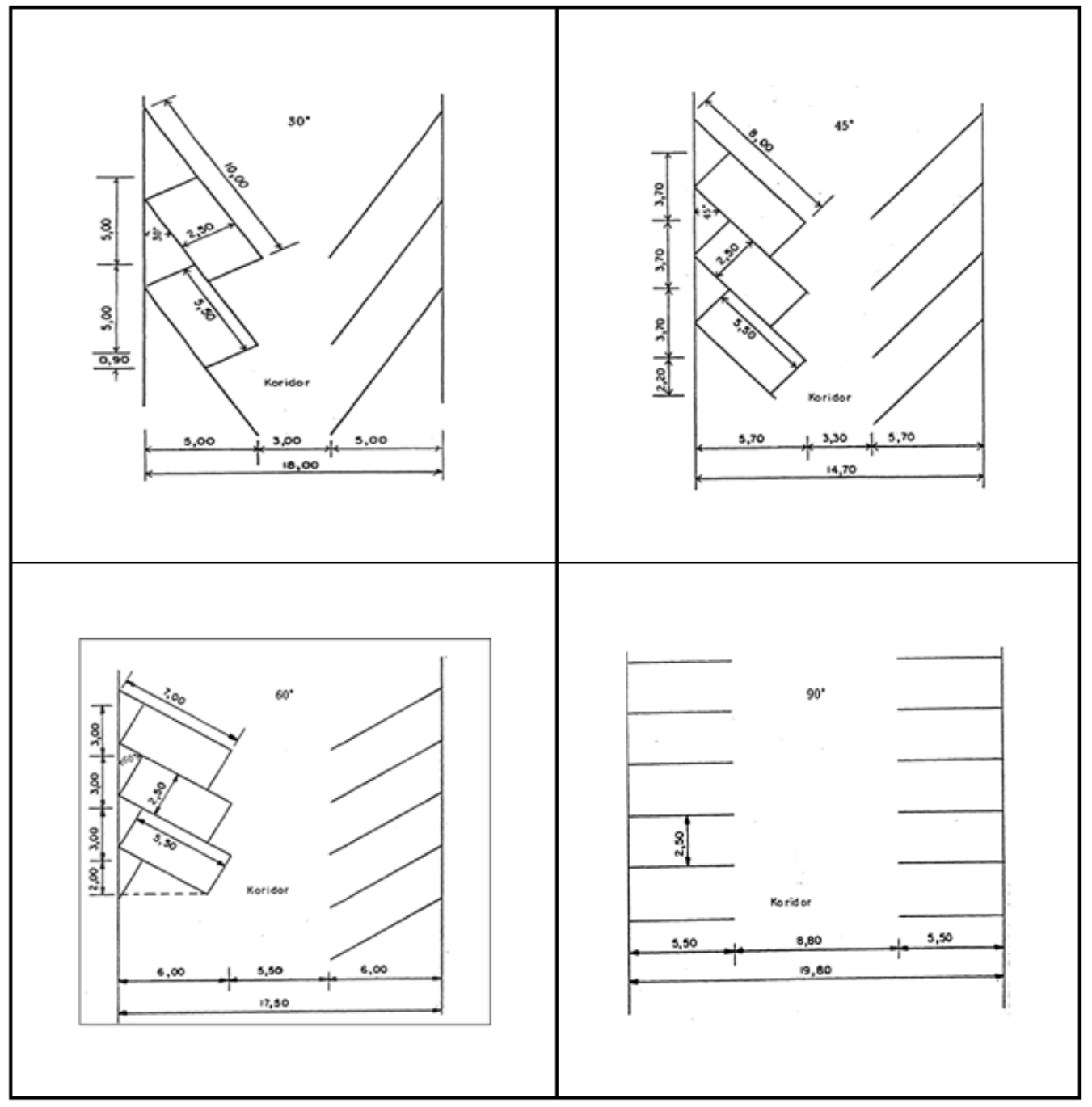

Şekil 1. Yol dışı park düzenleme şekilleri $[46,47]$

\subsubsection{Yol kenarı park düzenleme şekilleri}

Yol kenarı park yerlerinde, eksene paralel $30^{\circ}, 45^{\circ}, 60^{\circ}$ ve $90^{\circ}$ 'lik park şekilleri düzenlenebilir. Park açısı büyüdükçe, belirli bir yol uzunluğunda daha fazla araç park edilebileceği açıkça görülebilir. Ancak trafik şartları da yol daralmasından dolayı ağırlaşır, park alanlarına giriş ve çıkış hareketleri zorlaşır ve tehlikeli olur. Bu nedenle yol kenarı parklarda genellikle eksene paralel park şekli tercih edilmelidir. Bazı yerlerde park gereksinimi trafik akımından daha önemli olabilir. Bu gibi durumlarda açılı parklar kullanılmalıdır. Kent içi yerlerde park şekillerine göre park yeri belirlemesi TS 10551 'deki esaslara göre Tablo 2'de belirtilmiştir. 
Tablo 2. Yol kenarı park düzenleme şekilleri [44, 45]

Park Şekli

Standart Uzunluklar
L mesafede

park yeri $\mathrm{L}=\mathbf{1 0 0} \mathrm{m}$ için

sayısı

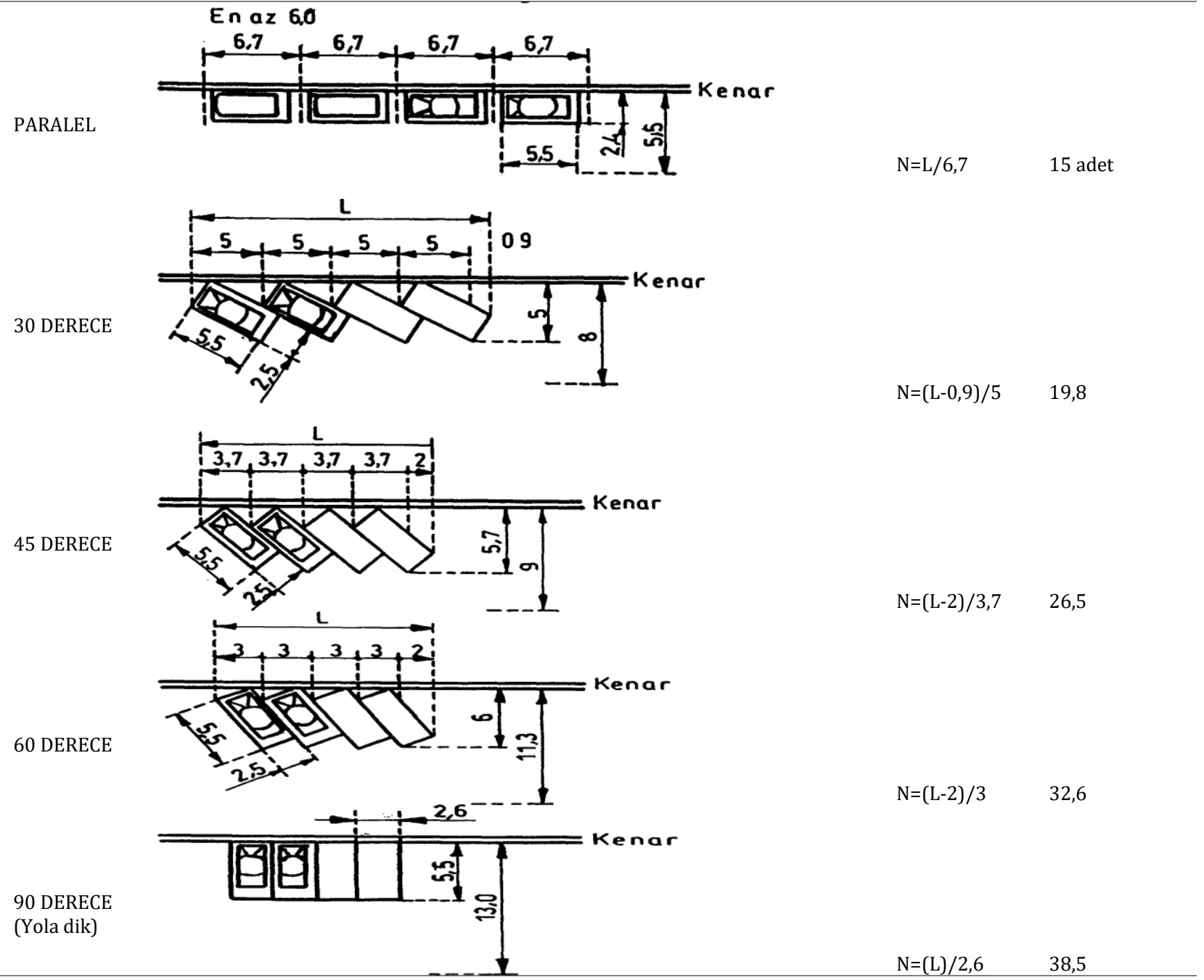

\section{Bulgular ve Tartışma}

Elâzı̆̆ ili özellikle son yıllarda gelişmekte olan iller arasındadır. Elâzı̆̆ ili yıllara göre nüfus ile ilgili bilgiler incelendiğinde son on yıl için ortalama nüfus artış1 \%0,875 olarak belirlenmiştir. Son on yılda otomobil ve kamyonet sayısı incelendiğinde ortalama artış yüzdesi sırasıla \% 7,04 ve \%8,61 olarak belirlenmiştir

Elâzığ'da kent merkezi ve ilçe merkezleri nüfus dağılımları incelendiğinde Nüfusun \%75 i Elâzığ şehir merkezinde olduğu belirlenmiştir. Otomobil ve kamyonet sayısına göre otopark ihtiyacı belirlenirken araç sayısının \%15 i alınarak belirlenmiştir. Nüfus ve araç sayıları dikkate alınarak Elâzı̆̆ ili otopark ihtiyaçları Tablo 3'de gösterilmiştir. 
Ahmet ATALAY, Yunus İÇEN

Tablo 3. Otopark İhtiyac1 [1]

\begin{tabular}{crr}
\hline Yıl & Nüfusa Göre & Araç Sayısına Göre \\
\hline 2009 & $9.581,2$ & $7.185,9$ \\
2010 & $10.570,4$ & $7.927,8$ \\
2011 & $11.700,4$ & $8.775,3$ \\
2012 & $12.737,8$ & $9.553,4$ \\
2013 & $13.748,8$ & $10.311,6$ \\
2014 & $14.715,4$ & $11.036,6$ \\
2015 & $15.841,0$ & $11.880,8$ \\
2016 & $16.970,4$ & $12.727,8$ \\
2017 & $18.148,4$ & $13.611,3$ \\
2018 & $19.025,2$ & $14.268,9$ \\
\end{tabular}

Elâzığ ili için ilerideki 20 yıl için otopark ihtiyacı belirlenirken yukarıda belirtilen ortalama nüfus artış oranı, ortalama otomobil ve kamyonet artış oranları dikkate alınarak belirlenmiştir. Nüfus, otomobil ve araç sayıları için başlangıç yılı değerleri 2018 yılı alınmıştır. 2018 -2038 yılları arasındaki otopark ihtiyacı Tablo 4'deki gibi elde edilmiştir.

Tablo 4. Elâzığ ili 2018-2038 yılları için otopark ihtiyacı [1]

\begin{tabular}{lll}
\hline Yıl & Nüfusa Göre & Araç Sayısına Göre \\
\hline 2018 & $19.025,2$ & $14.268,9$ \\
2019 & $20.442,2$ & $15.331,7$ \\
2020 & $21.965,7$ & $16.474,3$ \\
2021 & $23.603,8$ & $17.702,8$ \\
2022 & $25.365,0$ & $19.023,7$ \\
2023 & $27.258,8$ & $20.444,1$ \\
2024 & $29.295,2$ & $21.971,4$ \\
2025 & $31.485,0$ & $23.613,8$ \\
2026 & $33.840,1$ & $25.380,0$ \\
2027 & $36.372,8$ & $27.279,6$ \\
2028 & $39.096,8$ & $29.322,6$ \\
2029 & $42.026,6$ & $31.520,0$ \\
2030 & $45.178,0$ & $33.883,5$ \\
2031 & $48.567,8$ & $36.425,8$ \\
2032 & $52.214,2$ & $39.160,7$ \\
2033 & $56.137,0$ & $42.102,7$ \\
2034 & $60.357,1$ & $45.267,8$ \\
2035 & $64.897,5$ & $48.673,1$ \\
2036 & $69.782,5$ & $52.336,9$ \\
2037 & $75.038,7$ & $56.279,0$ \\
2038 & $80.694,5$ & $60.520,9$ \\
\hline
\end{tabular}

Çalışmanın birinci aşamasında ABD ve Almanya'da yapılan kabullere göre otopark ihtiyacı belirlemek için matematiksel formül ve araç sayısının \%15'ine göre Elâzığ ili için otopark ihtiyacı 2018-2038 yılları için ayrı ayrı belirlenmiştir. Yapılan hesaplamalar sonucu Elâzı ğ ilinin otopark ihtiyacı nüfusa göre 19.025 adet, araç sayısına göre 14.268 adet olarak belirlenmiştir. 2038 yılı için nüfusa göre 80.694 adet ve araç sayısına göre 60.520 adet belirlenmişsir.

\section{1. Elâzığ ili yol dışı parklar}

Kent içi park etüdü için yol dışı park etüdü yapılacak otoparklardan sadece merkezi trafiğin yoğun olduğu, iş merkezlerinin, özel hastaneler, bankalar, vergi daireleri, noterlerin en yoğun olarak bulunduğu yerlerde otopark sıkıntısının azami olarak hissedildiği alanlarda bulunan otoparklar seçilmiştir. Bu otoparklar; Polatlar kapalı otopark1, Doğu katlı otopark1, Hazar otoparkı, Hükümet Konağı kapalı otoparkı, İzzet Paşa kapalı otoparkı, İbrahim Ethem kapalı otoparkı, Enhas kapalı otoparkı, Müftülük Kapalı otoparklarıdır. Çalışma kapsamında 
seçilen otoparklardan başka otoparklar mevcuttur. Diğer otoparklar şehir merkezinin ikinci derece yoğun olduğu bölgelerinde bulunduğundan çalışma kapsamına dâhil edilmemiştir.

Yol kenarı park etüdü olarak da şehrin ana arterleri olan Gazi Caddesi, Vali Fahri Bey Caddesi ve Hürriyet Caddeleri seçilmiştir. Etüt çalışmaları 01.04.2019 ve 14.04.2019 sabah, öğle ve akşam olmak üzere 09.00-11.00, 13.00 15.00, 17.00-19.00 saatleri arasında 30 dakikalık aralıklarla yapılmıştır. Yol dışı parklar ve yol kenarı parklar için iki farklı sayım föyü hazırlanmıştır. Etütlerin sonuçlarına göre en yüksek doluluk oranı İbrahim Ethem ve Polatlar otoparklarında belirlenmiştir.

Tablo 5. Etüt yapılan otoparklar ile ilgili bilgiler [1]

\begin{tabular}{|c|c|c|c|}
\hline Kapalı Otopark Adı & Kapasitesi & Abone Sayısı & $\begin{array}{c}\text { Ortalama } \\
\text { Doluluk Oranları \% }\end{array}$ \\
\hline Polatlar Otoparkı & 50 & 30 & 61,96 \\
\hline Doğu Katlı Otoparkı & 600 & 200 & 35,17 \\
\hline Hazar Otoparkı & 250 & 120 & 50,17 \\
\hline Hükümet Konağ 1 Otopark1 & 500 & 100 & 24,29 \\
\hline İzzet Paşa Otoparkı & 100 & 50 & 58,74 \\
\hline İbrahim Ethem Otoparkı & 80 & 40 & 68,28 \\
\hline Enhas Otopark1 & 200 & 100 & 53,29 \\
\hline Müftülük Otoparkı & 100 & 40 & 44,07 \\
\hline
\end{tabular}

Çalışmanın ikinci aşamasında yol dışı otoparklar kapasite doluluk oranları incelenmiştir. Elâzı̆̆ ilinde bulunan Polatlar, Doğu katlı, Hazar, Hükümet Konağı, İzzet Paşa, İbrahim Ethem, Enhas, Müftülük kapalı otoparklar1 01.04.2019 - 14.04.2019 tarihlerinde ve 09.00-11.00, 11.00-13.00, 17.00- 19.00 saatlerinde yapilan gözlemler ile doluluk oranları tespit edilmiştir. Polatlar \%61,96, Doğu katlı \%35,17, Hazar \%50,17, Hükümet Konağ1 \%24,29, İzzet Paşa \%58,74, İbrahim Ethem \%68,29, Enhas \%53,29, Müftülük \%44,07 doluluk oranına sahip oldukları belirlenmiştir. Buna göre Polatlar ve İbrahim Ethem kapalı otoparkları en fazla doluluk oranına sahip olan kapalı otoparklardır. En düşük doluluk oranına sahip kapalı otoparklar ise Hükümet Konağı ve Doğu katlı otoparklarıdır.

Çalışmanın üçüncü aşamasında ülkemizdeki standartlar ve yönetmeliklere göre otoparkların incelenmesi yapılmıştır. Bu kapsamda TSE'nin TS 10551'nolu Türk Standardı ve 2018 yılında yayımlanan Otopark Yönetmeliği Esasları kullanılmıştır. Etüt çalışması yapılan otoparklardan Doğu katlı otoparkı, İbrahim Ethem ile Hükümet konağı otoparkının yönetmelik ve standartlara uygun olarak yapıldığı tespit edilmiştir. Polatlar kapalı otoparkında ise giriş çıkış rampa eğiminin \%15'ten fazla olmasından dolayı standartlara uygun olmadığı tespit edilmiştir. Hazar kapalı otoparkının giriş çıkış rampa eğiminin \%20'den fazla olduğu tespit edilmiştir. Dolayısıyla standartlara uygun değildir. İzzet Paşa kapalı otoparkının giriş çıkış kapı genişliğinin standartlara uygun olduğu ancak rampa eğiminin yaklaşık \%20’nin üzerinde olmasından dolayı standartlara uygun olmadığı tespit edilmiştir.

Enhas kapalı otoparkının giriş çıkış araç manevra mesafesinin dar olması sebebiyle standartlara uygun değildir. Müftülük kapalı otoparkının rampa eğimi \%15'ten fazla olması ve rampa genişliğinin dar olması sebebiyle standartlara uygun olmadığı tespit edilmiştir. 2018 yılında yayımlanan otopark yönetmeliğinde belirtildiği üzere; otopark giriş kapısı genişliği net 2,75 metreden az, giriş kapısı yüksekliği 2,00 metreden, otopark iç yüksekliği kiriş altı hiçbir yerde 2,10 metreden, otopark rampa genişliği 2,75 metreden az olamamalıdır. Umumi otoparklarda rampa eğimi \%15'ten fazla olmamalıdır.

\section{1. Elâzı̆̆ ili yol kenarı parklar}

Yol kenarı park etütleri 01.04.2019- 14.04.2019 tarihleri arasında yapılmıştır. Yapılan etütler sonucunda sabah, öğlen ve akşam olmak üzere yapılmış ve analiz süresince ortalama değerler belirlenmiştir. Yol kenarı park etütlerinde beş saatten fazla kullanım oranlarının yüksek olduğu tespit edilmiştir (Tablo 6).

Tablo 6. Elâzı̆̆ ili yol kenarı park etüt sonuçları [1]

\begin{tabular}{|c|c|c|c|c|c|c|c|}
\hline Cadde Adı & $\begin{array}{l}\text { Cadde } \\
\text { genișliği }\end{array}$ & Ortalama doluluk & $\begin{array}{l}1 \text { Saatten } \\
\text { az }\end{array}$ & $\begin{array}{l}2 \text { saatten } \\
\text { fazla }\end{array}$ & $\begin{array}{l}3 \text { saatten } \\
\text { fazla }\end{array}$ & $\begin{array}{l}4 \text { saatten } \\
\text { fazla }\end{array}$ & $\begin{array}{l}5 \text { saatten } \\
\text { fazla }\end{array}$ \\
\hline Gazi Caddesi & $10 \mathrm{~m}$ & 98,32 & 27,61 & 13,15 & 4,53 & 4,44 & 48,61 \\
\hline Vali Fahri Bey & $10 \mathrm{~m}$ & 97,42 & 26,92 & 7,91 & 6,48 & 3,85 & 52,53 \\
\hline Hürriyet Cad. & $\begin{array}{l}6 \mathrm{~m}+6 \mathrm{~m} \text { çift } \\
\text { yönlü }\end{array}$ & 97,87 & 25,29 & 5,46 & 4,54 & 3,03 & 59,58 \\
\hline
\end{tabular}


Çalışmanın dördüncü aşamasında yol kenarı park etütleri yapılmıştır. Gazi caddesi için, 1 saat ve daha az ortalama park oranı \%27,61 iken 5 saat ve daha fazla park etme oranı \%48,61'dir. Vali Fahri Bey Caddesi için, 1 saat ve daha az park etme oranı ortalama $\% 26,92$ iken bu oran 5 saat ve daha fazla park etme için $\% 52,53$ 'tür. Hürriyet Caddesi için, 1 saat ve daha az park edenler $\% 25,29,5$ saat ve daha fazla park edenlerin sayıs $1 \% 59,58$ 'dir. Beş saat ve daha fazla süre ile park etme oranının yüksek olmasının nedeni cadde üzerinde bulunan işyeri sahiplerinin araçlarını park etmek için yol kenarını kullanmalarıdır. Yol kenarı parklar yolun kapasitesini düşürmektedir. Ayrıca ikinci sıra park yapıldığı gözlemlenmiştir. Bundan dolayı yolda kuyruklanmalar oluşmaktadır.

Gazi Caddesinde yol kenarı parka müsaade edilen uzunluk 435 metredir. Genişliği 7,5 m-12 m olup tek yönlü akan trafikte açılı park etmek daha avantajlıdır. Gazi Caddesi yol kenarı mevcut paralel park yerine $30^{\circ}$ lik park edildiği takdirde $\% 22,45^{\circ}$ lik park edildiği takdirde $\% 64^{\prime}$ lük kapasite artışına ulaştı̆̆ı hesapla bulunmuştur.

\section{Sonuç ve Öneriler}

$\mathrm{Bu}$ çalışmada literatürde var olan yöntemler, standartlar ve yönetmelikler kullanılarak Elâzı̆̆ il merkezi ölçeğinde vaka çalışması yapılmıştır. Çalıșma bulgularından Elâzığ ilinde hem bugün hem de gelecek 20 yıl için yeni park yerine ihtiyaç olduğu tespit edilmiştir. Yapılan otopark ihtiyacı hesaplarına göre kentin mevcut otopark sayısı ve kapasitesi yetersiz olduğu tespit edilmiştir. Bugün bile yetersiz kalan bu oranın, 20 yıl sonrası için yapılan hesaplamalarda daha yüksek seviyelere ulaşacağı tespit edilmiştir.

Elâzığ gibi gelişmekte olan kentlerimizde gelecekte yaşanacak problemleri önlemek amacıyla ulaşım politikaları geliştirilmelidir. Kentlerde arazi kullanım planları ve ulaşım planları hazırlanırken resmi kurum ve kuruluşların, iş ve alışveriş merkezlerinin nerelerde konumlandırılacağı gibi faktörler dikkate alınarak gelecekteki trafiğgin tahmini doğru yapılmalıdır. Gelecekteki trafik belirlendikten sonra otopark planlaması yapılmalıdır. Otopark planlamaları yapılırken özel araç kullanımından ziyade bütünleşik bir toplu taşıma sistemine uygun şekilde planlanmalıdır. Örneğin otoparklar "park et-devam et" istasyonları olarak planlanmalıdır.

Çalışma kapsamında incelenen otoparklar 09.00-17.00 arasında maksimum doluluk oranına sahip oldukları, 17.00-19.00 saatleri arasında ise minimum doluluk oranına sahip oldukları tespit edilmiștir. Bunun sebebi otopark abonelerinin ağırlıklı olarak merkezi iş alanlarında çalışan bireylerden oluşması dolayısıyla mesai saatleri bitiminde araçlarını otoparktan almalarıdır. Otoparkların şehir merkezinde ticari merkezler ve resmî kurumların yoğun olarak bulunduğu alanlarda oldukları için hareketlilik 09.00-17.00 arasında yoğun olmaktadır. Dolayısıyla 09.00-17.00 saatleri dışında otoparklar minimum kullanım oranına sahiptir. Polatlar ve İbrahim Ethem kapalı otoparklarının doluluk oranlarının diğer otoparklara kıyasla daha fazla olmasının sebebi, bu iki otoparkın iș merkezlerinin altında bulunması ve otoparkları kullanan sürücülerin araçlarını park ettikten sonra asansör ile ana caddeye ulaşabilmeleri olarak düşünülmektedir. Hükümet Konağı ve Doğu katlı otoparklarının doluluk oranlarının düşük olmasının sebebi bu iki otoparkın kullanan taşıt sürücülerinin ana caddeye belirli bir mesafe yürümek zorunda kaldıklarından tercih edilmedikleri düşünülmektedir. Ayrıca bu iki otoparkın yeni faaliyete geçtiklerinden dolayı vatandaşlar tarafindan bilinmediği düşünülmektedir.

Doğu katlı otoparkı, İbrahim Ethem ile Hükümet konağı otoparkının yönetmelik ve standartlara uygun olarak yapıldığı tespit edilmiş̧tir. Çalışma kapsamında incelenen Polatlar, Hazar, İzzet Paşa ve Enhas otoparkları çalışma kapsamında dikkate alınan standart ve yönetmeliğe uymadıkları tespit edilmiştir.

Yol kenarı parklar için üç ana caddede yapılan etütler neticesinde, park etme doluluk oranları \%100'e yakındır. Ancak caddelerin üçünde de paralel park yapılmaktadır. Paralel park sebebiyle park yeri sayısı oldukça düşüktür.

Yol kenarı ikinci sıra parklanmalar sonucu yolların kapasitesi düşmekte ve trafik tıkanıklı̆̆ı oluşmaktadır. Bundan dolayı zaman, yakıt tüketimi ve karbon salınımı artmaktadır. Bunu önlemek için yol kenarı parkı yasaklamak veya caydırıcı tedbirler almak gerekmektedir. İkinci sıra park yapmaya izin verilmemeli, cadde mobesse kameralarından devamlı izlenilip kural dışı park eden sürücüler için caydırıcı parasal yaptırımlar uygulanmalıdır. Caydırıcı tedbirler için süre ile orantılı ücretlendirme yapılmalıdır. Yol kenarı park ücreti yüksek olduğu zaman kullanıcılar kapalı otoparkları kullanma ihtiyacı duyacaklardır.

Vali Fahri Bey ile Hürriyet Caddelerinin genişliklerinin yeterli olmaması sebebiyle açılı park yapılmasına uygun olmadıkları tespit edilmiștir. Kentin merkez caddeleri olan Hürriyet, Gazi ve Vali Fahri Bey Caddelerinde trafik akımının sürekliliğini sağlamak için trafik polisleri ve belediye zabıtaları tarafından denetimlerin arttırılması ve kurallara uymayan sürücüler için cezai yaptırımlar uygulanmalıdır.

$\mathrm{Bu}$ çalışmada gündüz saatlerinde kapalı otoparkların ve yol kenarı parkların doluluk oranları yüksek olduğu, akșam saatlerinde ise minimum seviyede olduğu tespit edilmiștir. Bunun nedeninin inceleme yapılan otoparkların bulunduğu bölge ticari alanlar, resmi kurum ve kuruluşların yoğun olduğu bölgeler olduğu için trafik 
hareketliliğinin gündüz mesai saatleri içerisinde otopark talebini fazla olmaktadır. Bunun yanı sıra akşam saatlerinde talep azalmasından dolayı doluluk oranlarında azalma olmaktadır. Kapalı otoparklar ile yol kenarı park yerlerindeki doluluk oranları karşılaştırıldığı zaman yol kenarı parkların doluluk oranları daha yüksektir. Bunun nedeni yol kenarı parklar ücretsiz ve park yapma açısından daha pratik olmasından kaynaklanmaktadır.

İmar planları hazırlanırken ulaşım konusunda deneyimli teknik elemanlar tarafından daha kapsamlı etüt planlama çalışmaları yapılmalıdır. Kentin yöneticileri tarafından ulaşım ile ilgili kararlar alınırken vatandaşların düşüncelerinin dikkate alınması daha faydalı olacaktır. Bunun için anket çalışmaları yapılıp sonuçlar değerlendirilerek karar verilmelidir. Elâzı̆̆ gibi gelişmekte olan illerin ilerleyen zamanlarda ulaşım problemlerinin daha karmaşık hal almaması için ulaşım planının yaptırılması gerekmektedir. Yapılacak ulaşım planlamasında şehrin arazi kullanımı, sosyo-ekonomik yapısı, kültürel ve tarihi yapısı göz önünde bulundurulmalıdır. Ulaşım planlaması yapıldıktan sonra kararlı bir şekilde planın uygulanması faydalı olacaktır.

Gelecekte yapılacak çalışmada Elâzı̆̆ ili şehir merkezinde bulunan bütün otoparklar çalışmaya dahil edilerek problem daha geniş bir çerçevede ele alınması faydalı olacaktır.

\section{Teşekkür}

Bu çalışmada A.A., fikir sahibi, Y.İ., sahada ölçümleri gerçekleştirdi, çalışmanın veri tabanını oluşturdu, A.A., ve Y.İ., makaleyi yazdı ve sonuçları yorumladı, A.A., yayınlama aşamasındaki işlemleri gerçekleştirdi.

\section{Kaynaklar}

[1] İçen, Y., Elaziğ İli Kentiçi Otopark Sorununun İncelenmesi, Yüksek Lisans Tezi, Atatürk Üniversitesi, Fen Bilimleri Enstitüsü, Erzurum, Türkiye, 2019.

[2] Evren G.,İstanbul Ulaştırması Yönetimi sorunu ve Sürdürülebilir Ulaştırma Bağlamında Bir Değerlendirme, Ulusal Toplu Ulaşım Sempozyumu ve Sergisi, İstanbul, 2010.

[3] Sevginer c., Bilge E, Demir Ö., Gezer U.Y., Sürdürülebilir Ulaşım İçin Çözüm Önerisi: Taksiye Yönelik araç Platformu, 9. Ulaştırma Kongresi, İstanbul, 2011.

[4] Haldenbilen, S., Murat,Y.Ş., Baykan,N.,Meriç,N., Kentlerde Otopark sorunu:Denizli Örneği.Pamukkale Üniversitesi Mühendislik Fakültesi Mühendislik Bilimleri dergisi,1999, 5(2-3),1099-1108.

[5] Yarbaşı, S., Erzurum Kentiçi Ulaşım Sorunlarından Otoparklar Üzerine Bir Araştırma. Y.Lisans Tezi, Fen Bilimleri Enstitüsü,Erzurum, Türkiye, 2002.

[6] Baerwald, J.E., Transpottation And Traffic Engineering Handbook,nstitue of Transportation Engineers, New Jersay , ISBN: 0-13-930578-5,655 p, 1965.

[7] Manville, M., ve Shoup, D., Parking, People, and Cities, Journal Of Urban Planning And Development, 13142: 233-245, 2005

[8] Güngör, E.K., Konya Şehir Merkezindeki Otopark Sorunu Ve Öneriler.Y.Lisans Tezi,Fen Bilimleri Enstitüsü, Konya, Türkiye, 2006.

[9] Kan, H., İstanbul ili, tarihi yarımada ve yakınÇevresinin mevcut otopark envanteri ve Araç park etme sorununa ait çözümStratejileri.Y.Lisans Tezi,Sosyal Bilimleri Enstitüsü,İstanbul,Türkiye. 2017.

[10] Edwards, J., The Main Street Parking Initiative", Institute of Transportation Engineers, ITE Journal, Nov 2006, 76-11: 30, 2006.

[11] Moore, B., Downtown Parking in Small Communities, The Review Magazine, 81-1: 17-19, 2008.

[12] İskender, E., Otopark Etüt Metodolojisi İçin Gerçek Zamanlı Saha Araştırma Sisteminin Tasarımı Ve Uygulama Örnekleri.Y.Lisans Tezi,Fen Bilimleri Enstitüsü,İstanbul, Türkiye2010.

[13] O'flaherty, C.A., Design of off-street parking facilities, Transport Planning and Traffic Engineering, USA, Elsevier, 1996, 409-434.

[14] Çiçek, C., Otoparklarda Kullanılan Yeni Teknolojilerin Türkiye'de Uygulanabilirliğinin Araştırılması.Y.Lisans Tezi,Fen Bilimleri Enstitüsü,Eskişehir,Türkiye. 2015.

[15] Uyur, E., Otopark Sorununun Arz Ve Talep Temelinde İncelenmesine Yönelik Bir Araştırma: Kadıköy Merkez Örneği.Y.Lisans Tezi,Fen Bilimleri Enstitüsü,İstanbul,Türkiye. 2015.

[16] Council, F.B., "Transportation Demand Management; A Small and Mid-Size Communities Toolkit”, 2009, http://www.fraserbasin.bc.ca/_Library/CCAQ/toolkit_tdm_2009.pdf, 14 Aralık 2014.

[17] Şahin, A., Otopark Geliştirme Analizi: İstanbul Merter Yer Altı Otoparkı Örneği.Y.Lisans Tezi,Fen Bilimleri Enstitüsü,İstanbul, Türkiye, 2009.

[18] Özen, M., Küçük Kentlerde Otopark Planlaması Ve Yönetimi.Y.Lisans Tezi,Fen Bilimleri Enstitüsü, İstanbul, Türkiye, 1965. 
[19] Gülhan, G.ve Ceylan,H., Otopark Sorununa Otopark Yönetimi temelinde Yaklaşımlar:İzmir Örneği.Dokuz Eylül Üniversitesi Mühendislik fakültesi Mühendislik bilimleri Dergisi,12(1),63-73, 2010.

[20] Taş, C., Kent içi otoparkların planlama ve yönetimUygulamalarının incelenmesi.Y.Lisans Tezi,Fen Bilimleri Enstitüsü,İstanbul,Türkiye, 2012.

[21] Hajımohammadipour, O., An investigation of Surface parking lots and developing design strategies.M.sc. thesis, graduate school of science engineering and technology, İstanbul,Turkey. 2015.

[22] Karaağaç, İ., Hastane Projelerinin Otopark Planlamasında Dikkate Alınacak Hususların İncelenmesi.Y.Lisans Tezi,Fen Bilimleri Enstitüsü,Eskişehir,Türkiye. 2017.

[23] Balsas C.J.L, Sustainable transportation planning on college campuses”, Transport Policy, 10 (2003): 35-49, 2002.

[24] Kılıç, D., Atatürk üniversitesi doğu Kampüsü otopark sorununun Değerlendirilmesi.Y.Lisans Tezi,Fen Bilimleri Enstitüsü,Erzurum,Türkiye. 2019.

[25] Tozluoğlu, Ç., Park yapma alışkanlıklarının analiz edilmesi ve uygulamaBölgesi için otopark politikaları önerisi.Y.Lisans Tezi,BilişimEnstitüsü,İstanbul,Türkiye. 2017.

[26] Salman, A.I., Analysing of parking sysytems for on-street and off-street: case study for İstanbul. M. Sc. Thesis, Graduate School Of Science Engineering and Technology, Istanbul,Turkey. 2017.

[27] Abboud, N.W., Automation of Parking Industry : A Strategic andManagerial Overwiev, M. Sc. Thesis, Mussachussetts Institute of Technology, ABD, 17-19, 36, 43, 44, 47, 48. 1994.

[28] Altun, F., Ak1llı Otopark Sisteminin Tasarım ve simülasyonu.Y.Lisans Tezi,Fen Bilimleri Enstitüsü,Kayseri,Türkiye. 2001.

[29] Pala, Z., Rfid teknolojisi İle otomasyon Bir uygulama olarak: otopark takibi.Y.Lisans Tezi,Fen Bilimleri Enstitüsü,İstanbul,Türkiye. 2007.

[30] Erdoğdu, E., Dairesel yapıda bir otomatik otopark sistemininPrototip tasarımı ve uygulaması.Y.Lisans Tezi,Fen Bilimleri Enstitüsü,Ankara,Türkiye. 2015.

[31] Karasay, T., Mekanik Otopark Tesislerinin Yer Seçimi Ve Boyutlandırılması İçin Genetik Algoritma Tabanlı Bir Yaklaşım.Y.Lisans Tezi,Fen Bilimleri Enstitüsü,İstanbul,Türkiye. 2016.

[32] Güngör, A., Akıllı Şehir Otopark Sistemlerinde Nfc Kartların Ödeme Aracı Olarak Kullanılması Ve Güvenlik Alt Yapısı; İspark Ve İstanbul Kart Örneği.Y.Lisans Tezi,Fen Bilimleri Enstitüsü,İstanbul,Türkiye. 2017.

[33] Yıldırım, G., Mobil uygulamalarda arayüz tasarımıkapalı otoparklar için IPS kullanılan mobil uygulama.Y.Lisans Tezi, Sosyal Bilimleri Enstitüsü,İstanbul,Türkiye. 2017.

[34] Sayın, M., Otopark Kılavuz Bilgi Sistemi Uygulamaları: Ankara İçin Örnek Bir Uygulama Çalışması.Y.Lisans Tezi,Fen Bilimleri Enstitüsü,Ankara,Türkiye. 2019.

[35] Özdemir, V.İ., Park et ve devam et tesisler ve Harem otoparkı örneği.Y.Lisans Tezi,Fen Bilimleri Enstitüsü,İstanbul,Türkiye. 2006.

[36] Barhani, E., Parkıng management strategıes for sustaınableTransportatıon:A case study for İstanbul.Master of Science, graduate school of science engineerıng and technology, İstanbul,Turkey. 2007.

[37] Okubay, M., BölgeselOtopark yönetimi ve stratejileri:Tarihi yarımada - eminönü bölgesi örneği.Y.Lisans Tezi,Fen Bilimleri Enstitüsü,İstanbul,Türkiye. 2008.

[38] Selim, C., Otopark alanlarının planlama ve Tasarım ilkeler.: Ege üniversitesiYerleşkesi örneği.Y.Lisans Tezi,Fen Bilimleri Enstitüsü,İzmir,Türkiye. 2011.

[39] Akyüz, M.H., Kent içi üniversite kampüslerindeOtopark planlaması ve yönetimi:Yıldız teknik üniversitesi merkez kampüsü örneği.Y.Lisans Tezi,Fen Bilimleri Enstitüsü,İstanbul,Türkiye. 2016.

[40] Yıldırım, H., Otopark alanlarının tasarımı ve kullanıcı Taleplerinin Süleyman Demirel üniversitesi yerleşkesi Örneğinde irdelenmesi.Y.Lisans Tezi,Fen Bilimleri Enstitüsü,Isparta,Türkiye. 2019.

[41] Sabitoğlu, B., Alternatif bir yeşil alan modeli olarak otopark üstü park ve bahçeler İstanbul Esenler nenehatun parkı örneği.Y.Lisans Tezi,Fen Bilimleri Enstitüsü,İstanbul,Türkiye. 2011.

[42] Kozal1, B., Kamusal Bir Mal Olarak Kentiçi Otopark Alanları.Y.Lisans Tezi,Sosyal Bilimleri Enstitüsü,İstanbul,Türkiye. 2014.

[43] Uzun, M., Kamu Ve Özel Otopark İşletmelerinde Hizmet Kalitesinin Ölçümü Ve Mukayesesi.Y.Lisans Tezi,Dış Ticaret Enstitüsü,İstanbul,Türkiye. 2017.

[44] TUİK, www.tuik.gov.tr, 2019

[45] Özdirim, M., Trafik Mühendisliği KGM, Ankara, Türkiye, 1994.

[46] Anonim, Türk Standartları Enstitüsü TS 10551, 1992.

[47] Anonim, Otopark yönetmeliği 30340, 2018. 